\title{
Salt taste after bariatric surgery and weight loss in obese persons
}

Cem Ekmekcioglu, Julia Maedge, Linda Lam, Gerhard Blasche, Soheila Shakeri-Leidenmühler, Michael Kundi, Bernhard Ludvik, Felix B Langer, Gerhard Prager, Karin Schindler, Klaus Dürrschmid

Background: Little is known about the perception of salty taste in obese patients, especially after bariatric surgery. Therefore, the aim of this study was to analyse possible differences in salt detection thresholds and preferences for foods differing in salt content in obese persons before and after bariatric surgery with weight loss compared to nonobese individuals. Methods: Sodium chloride detection thresholds and liking for cream soups with different salt concentrations were studied with established tests. Moreover a brief salt food questionnaire was assessed to identify the usage and awareness of salt in food. Results: The results showed similar mean sodium chloride detection thresholds between non-obese and obese participants. After bariatric surgery a non-significant increase in the salt detection threshold was observed in the obese patients (mean \pm SD: $0.44 \pm 0.24 \mathrm{~g} \mathrm{NaCl} / \mathrm{L}$ before OP vs. $0.64 \pm 0.47 \mathrm{~g} \mathrm{NaCl} / \mathrm{L}$ after OP, $p=0.069$ ). Cream soup liking between controls and obese patients were not significantly different. However, significant sex specific differences were detected with the tested women not liking the soups ( $p<0.001$ ). Results from the food questionnaire were similar between the groups. Conclusion: No differences between non-obese persons and obese patients were detected regarding the taste of salt. However, due to highly significant differences in soup liking, sex should be taken into consideration when conducting similar sensory studies. 


\section{Manuscript to be reviewed}

\section{Salt taste after bariatric surgery and weight loss in obese}

\section{persons}

Short title: salt taste and obesity

Cem Ekmekcioglu ${ }^{1}$, Julia Maedge ${ }^{1,2}$, Linda Lam $^{1,2}$, Gerhard Blasche ${ }^{1}$, Soheila Shakeri-Leidenmühler ${ }^{3}$, Michael Kundi ${ }^{1}$, Bernhard Ludvik${ }^{4}$, Felix

B. Langer ${ }^{3}$, Gerhard Prager ${ }^{3}$, Karin Schindler ${ }^{5}$, Klaus Dürrschmid ${ }^{6}$

${ }^{1}$ Institute of Environmental Health, Centre for Public Health, Medical University of Vienna, Kinderspitalgasse 15, 1090-Vienna, Austria

${ }^{2}$ Department of Nutritional Sciences, University of Vienna, A-1090 Vienna, Austria

${ }^{3}$ Department of Surgery, Division of General Surgery, Medical University of Vienna, General Hospital Vienna, A- 1090, Vienna, Austria

${ }^{4}$ 1. Medical Department, Rudolfstiftung Hospital Vienna, Austria

${ }^{5}$ Department of Internal Medicine III, Division of Endocrinology and Metabolism, Medical University of Vienna, Vienna

${ }^{6}$ Food Sensory Science, Department of Food Science and Technology, BOKU University of Natural Resources and Life Sciences, Vienna, Austria

\section{*Corresponding Author and request for reprints:}

Cem Ekmekcioglu, MD

Institute of Environmental Health

Centre for Public Health

Medical University Vienna

Kinderspitalgasse 15

A-1090 Vienna

Austria

Phone.: +43-1-40160-34927

email: cem.ekmekcioglu@meduniwien.ac.at 


\begin{abstract}
Background: Little is known about the perception of salty taste in obese patients, especially after bariatric surgery. Therefore, the aim of this study was to analyse possible differences in salt detection thresholds and preferences for foods differing in salt content in obese persons before and after bariatric surgery with weight loss compared to non-obese individuals.
\end{abstract}

Methods: Sodium chloride detection thresholds and liking for cream soups with different salt concentrations were studied with established tests. Moreover a brief salt food questionnaire was assessed to identify the usage and awareness of salt in food.

Results: The results showed similar mean sodium chloride detection thresholds between non-obese and obese participants. After bariatric surgery a non-significant increase in the salt detection threshold was observed in the obese patients (mean \pm SD: $0.44 \pm 0.24 \mathrm{~g} \mathrm{NaCl} / \mathrm{L}$ before $\mathrm{OP}$ vs. $0.64 \pm 0.47 \mathrm{~g} \mathrm{NaCl} / \mathrm{L}$ after $\mathrm{OP}, \mathrm{p}=0.069$ ). Cream soup liking between controls and obese patients were not significantly different. However, significant sex specific differences were detected with the tested women not liking the soups $(\mathrm{p}<0.001)$. Results from the food questionnaire were similar between the groups.

Conclusion: No differences between non-obese persons and obese patients were detected regarding the taste of salt. However, due to highly significant differences in soup liking, sex should be taken into consideration when conducting similar sensory studies. 


\section{Manuscript to be reviewed}

\section{Introduction}

Reaching epidemic dimensions a high body mass index (BMI) belongs to the top risk factors for disability adjusted life years worldwide (Lim et al. 2012). Beside environmental, social and genetic factors, the main cause of obesity is a positive energy balance with an increased consumption of energy dense foods high in sugar and fat, in combination with a lack of physical activity.

In addition to a variety of well known co-morbidities, obese people tend to also have different taste and smell perceptions, which can influence their choice of food (Drewnowski 1997). Obese children for example identified taste qualities like salty, umami and bitter less precisely compared to children and adolescents of normal weight (Overberg et al. 2012). Also overweight/obese adults perceived sweet and salty tastes as less intense (-23\% and $-19 \%$, respectively) than normal-weight controls (Sartor et al. 2011). On the other hand, Pasquet et al. described that massively obese adolescents had higher taste sensitivity than lean controls, especially for sucrose and salt (Pasquet et al. 2007). Furthermore, not only humans but also obese mice show an altered perception of taste (Maliphol et al. 2013).

In previous investigations alterations in taste perception were shown after bariatric surgery and patients found certain foods repulsive and had developed aversions (Tichansky et al. 2006). Obese women showed decreased cravings for fast food and sweets and decreased preference for high sucrose concentrations after bariatric surgery and weight loss (Pepino et al. 2014). However, no alterations in taste sensitivity for sweet, salty and savory stimuli were detected.

Former studies especially investigated a change in sweet taste perception of obese people after bariatric surgery, whereas other studies detected an upregulation in bitter and sour taste acuity after surgery (Bueter et al. 2011; Scruggs et al. 1994). Regarding bariatric surgery and salt perception, only few studies are available, with inconsistent results (Scruggs et al. 1994; Pepino et al. 2014).

Due to the sparse and inconsistent data, this study aims to clarify the effect of bariatric surgery on salty taste by analysing the differences in the taste perception of salt of obese persons before and after bariatric surgery in comparison with a non-obese control group. Measurement of salt detection thresholds and analysis of hedonic liking of soups were applied to evaluate physiological and practical aspects. 


\section{Manuscript to be reviewed}

The relevance of the study is especially twofold. First, a potential variation of salt taste in obesity and after weight loss is of chemosensory and physiological interest. In addition, it is well known that a high salt intake is associated with hypertension (Ekmekcioglu et al. 2013), but probably also obesity (Ma et al. 2015). Therefore a modified salt taste in obese individuals, before or after weight loss, could influence their salt eating behavior and in turn their blood pressure and energy intake.

\section{Materials and Methods}

\section{Participants}

33 obese patients undergoing bariatric surgery (Roux-en-Y- or omega loop gastric bypass) were recruited on a voluntary basis at the Vienna General Hospital (Table 1). Physical examination was performed before and after bariatric surgery and the health status was documented. The test took place one day before patients underwent bariatric surgery and 3 months after surgery. However, only 19 participants (58\%) attended the second test due to personal and organizational issues. Age, sex distribution and BMI of the drop outs were not significantly different from the group who participated at the second test. The control group consisted of healthy persons with a BMI between 16 and 28 (Table 1). The sex distribution between the controls and the patients was not significantly different as analysed by a $\chi^{2}$-test.

In relation to previous similar studies (Pepino et al. 2014; Bueter et al. 2011; Scruggs et al. 1994; Burge et al. 1995) the sample size of the present study can be regarded as sufficient, having enough power to detect significant effects.

Informed written consent was obtained by all participants and the project was approved by the ethics committee of the Medical University of Vienna (EK Nr.: 1193/2013).

\section{Sensory evaluation}

Salty taste detection thresholds were assessed with the "Standard Practice for Determination of Odor and Taste Thresholds By a Forced-Choice Ascending Concentration Series Method of Limits”, which is a standard practice developed by ASTM International (American Society for Testing and Materials - ASTM 2011). The 


\section{Manuscript to be reviewed}

3 alternative forced choices ( 3 AFC) test was used to identify the threshold of the participants (Peng et al. 2012). In eight blocks increasing sodium chloride solutions ( 0.003 to $\sim 0.034 \mathrm{~mol} / \mathrm{L}$ or $\sim 0.16 \mathrm{~g} / \mathrm{l}$ to $\sim 2 \mathrm{~g} / \mathrm{L}$; ISO 3972 Standard) were tested. Each block consisted of two stimuli of distilled water $(20 \mathrm{ml})$ and one sodium chloride stimulus $(20 \mathrm{ml})$ in increasing concentrations. The test samples were labelled with random three-digit numbers, so that the participants were not able to identify the plastic vessels with the salt. After tasting each block the study persons had to indicate the sample that tasted different. They rinsed their mouth with tap water before tasting each block.

Based on the correct/incorrect responses of each participants an individual bestestimated threshold was calculated. An example for two participants is shown in Table 2.

The best-estimate threshold for test person number 1 is: $\sqrt{0.48 \times 0.69}=0.58 \mathrm{~g} \mathrm{NaCl} / \mathrm{L}$. The BET for test person number 2 is: $\sqrt{0.69 \times 0.98}=0.82 \mathrm{~g} \mathrm{NaCl} / \mathrm{L}$

\section{Assessment of the preference for soups differing in salt concentrations}

Cream soups with increasing salt concentrations were prepared with tap water, sour cream, and flour. The six $\mathrm{NaCl}$ concentrations of soups varied from $0.051 \mathrm{~mol} / \mathrm{L}(\sim 3$ $\mathrm{g} / \mathrm{L})$ to $0.154(\sim 9 \mathrm{~g} / \mathrm{L})$ in $0.026 \mathrm{~mol} / \mathrm{L}$ steps. For the production of one liter of soup, 35g of wheat flour (brand “Clever”) and one cup of sour cream (250g, brand “milfina”, 15\% fat) were blended and $250 \mathrm{ml}$ of tap water was added to the flour-sour cream mixture and stirred together. By using a funnel the mixture was filled in a 1L volumetric flask. Residues in the bottle were dissolved with water and transferred into the volumetric flask until all visible residues were removed. The bottle was then filled up with water to $1 \mathrm{~L}$ and was shaken intensively. Afterwards the content was divided into five $200 \mathrm{ml}$ glass bottles for heating in a stirring block thermostat. The bottles were closed throughout the entire cooking process to prevent the evaporation of the soup. To avoid agglutination or burning of the ingredients at the bottom of the bottles a magnetic stirrer was used during cooking. The different concentrations of salt (brand "Bad Ischler Tafelsalz”) were added after the soup reached the temperature of $60{ }^{\circ} \mathrm{C}$ and the content of the bottles were stirred again. After cooking, the soups were poured into $20 \mathrm{ml}$ plastic cups, closed with numbered plastic lids and deep frozen at $-20{ }^{\circ} \mathrm{C}$. For the 


\section{Manuscript to be reviewed}

sensory tests portion of soup were reheated in a microwave to $50{ }^{\circ} \mathrm{C} \pm 1$ just before testing.

A 9-point hedonic scale, with intervals from 1 (dislike extremely) to 9 (like extremely), was used to assess the preference of the participants' liking for the five different soups (Table 3).

\section{Food Questionnaire}

A food questionnaire which included eight questions about the preference for salty foods, use of salt in the preparation of meals, and awareness for salt in foods was completed by the study participants.

The questions were:

- I like to eat.... (unsalted to very salty).. meals

- I..... (never to always)... add salt to my meals

- How much salt do you add into water, when cooking two portions of spaghetti (approx. $300 \mathrm{~g})$ ?

- How frequently do you eat ham, sausages or bacon?

- How frequently do you eat convenience products (for ex. pizza, packet soups, deep frozen dishes)?

- How often do you eat salty nuts, chips, popcorn or similar salty snacks?

- Which of the listed foods below (sausages, raw meat, uncooked spaghettis, bread, milk, cheese, fresh vegetables, nuts, convenience foods, and chocolate) are high or low in salt?

- Do you think that dietary salt has negative/positive/no effects on our health?

The questions were taken from previous studies addressing the eating or salt behavior of adults and partly modified according to Austrian eating habits and conditions (Bundesministerium für Verbraucherschutz Ernährung und Landwirtschaft 2008; Kim et al. 2007; Parmenter and Wardle 1999; Webster et al. 2010).

\section{Statistics}

Differences in the mean values of estimated thresholds between patients and controls were analysed with a Mann-Whitney-U-test, since the data were not normally 


\section{Manuscript to be reviewed}

distributed. Comparison between estimated thresholds before and after surgery in the patient group was done by a Wilcoxon-test.

Soup liking between patients vs. controls was analysed with an univariate analysis of variance with the weighted mean of the soup liking (soup 1 was weighted with 1 and soup 5 with 5) as the dependent variable, group and sex as factors and age and BMI before surgery as covariates.

Differences in soup liking before and after surgery in the patients were calculated by an analysis of repeated measures with age, sex and the difference in BMI (before and after surgery) as covariates. Tests for inner subject contrasts were used to analyse differences between the soups.

Data from the food questionnaire were compared with an unpaired t-test between the two groups.

The statistical analysis was performed on IBM SPSS 22 Statistics with p values of less than 0.05 being regarded as significant.

\section{Results}

\section{Estimated salt detection thresholds}

No statistical difference was observed between the salt detection thresholds of the controls (mean \pm SD: $0.49 \pm 0.45 \mathrm{~g} \mathrm{NaCl} / \mathrm{l}$ ) compared to the obese group (mean $\pm \mathrm{SD}$ : $0.51 \pm 0.34 \mathrm{~g} \mathrm{NaCl} / \mathrm{l}$ ) (Fig. 1A). Furthermore, a non-significant increase in the salt detection threshold of the patients was observed after bariatric surgery (mean \pm SD: $0.44 \pm 0.24 \mathrm{~g} \mathrm{NaCl} / \mathrm{L}$ before OP; $0.64 \pm 0.47 \mathrm{~g} \mathrm{NaCl} / \mathrm{L}$ after OP, $\mathrm{p}=0.069$ ) (Fig 1B). No sex specific differences were detected. Furthermore there were no significant differences in the salt detection thresholds between patients with or without diabetes or hypertension.

\section{Soup liking}

Cream soups with five different salt concentrations in increasing order (soup 1 lowest, soup 5 highest salt concentration) were used to test the soup preference on a 9 point 


\section{Manuscript to be reviewed}

hedonic scale. The results showed that the control group liked the soup 2 best $(4.24 \pm$ 2.33), whereas patients before surgery preferred soup 4 most (Table 4).

However statistical analysis showed no significant differences between controls and patients before surgery when using the weighted mean of the soup liking as the dependent variable (Fig. 2A).

Interestingly, we found highly significant sex specific differences in the soup liking ( $\mathrm{p}<$ 0.001; Fig 2B), suggesting that the tested women did not like the soups.

In addition, the soup liking before and after surgery were not significantly different in the patient group. Also, contrast analyses showed no significant differences between the soups.

\section{Food questionnaire}

The food questionnaire was completed by 15 controls and 26 obese patients after testing the salt detection thresholds and soup liking at the first visit. Except for the question asking for the salt content of chocolate no significant differences were found between the two groups. Major results from the questionnaire showed that the participants in both groups ate moderately salted foods, rarely added salt to cooked dishes, ate ham, sausages or bacon 1-2 times per week, and ate convenience products or salty chips and similar snacks 2-3 times per month (for data, please refer to the supplemental data file).

\section{Discussion}

The present study showed that the salt detection thresholds and soup liking of obese patients were not significantly different from healthy, non-obese controls. In addition, a non-significant increase in the salt detection threshold was observed in patients after bariatric surgery. An unexpected result was that the tested women did not like the cream soups.

In several studies, the association between taste perception and obesity was evaluated, with a special focus on sweet taste (reviewed in (Donaldson et al. 2009)). However, the results in these studies were partly contradictory, possibly because different techniques were used (Donaldson et al. 2009). 
Regarding obesity surgery and taste, one of the first studies in the mid 1970s showed that one year after intestinal bypass surgery and significant weight loss obese patients rated the pleasantness of a $40 \%$ sucrose solution lower than before surgery (Bray et al. 1976). In another study, the recognition threshold for sucrose fell from $0.047 \mathrm{~mol} / \mathrm{L}$ to 0.019 mol/L 12 weeks after Roux-en-Y gastric bypass (Burge et al. 1995).

Also Bueter et al. investigated changes of sweet taste perception in 9 obese patients 2 months after gastric bypass surgery. They found that even though patients were able to detected lower concentrations of sucrose after the operation as compared to before, no differences in hedonic ratings of sucrose solutions were found (Bueter et al. 2011). Therefore, although measurements of taste detection thresholds are established physiological methods to study the function of sensory receptors and gustatory circuits they do not necessarily correlate with suprathreshold intensity or hedonic values (Bueter et al. 2011; Spector 2000; Bartoshuk 1978; Webb et al. 2015). For example, in a recent comparison of five methods to assess taste function it was shown that detection thresholds were not correlated with suprathreshold intensities of any taste quality, including sodium chloride (Webb et al. 2015).

Regarding salty taste and obesity, only a few studies are available. In a study from Pasquet et al. for example, lower recognition thresholds for sucrose and sodium chloride were found in obese adolescents compared to the lean control group (Pasquet et al. 2007). In another study it was shown that overweight women liked the taste of salty foods more compared to the normal weight group; however converse results were seen in the male control group (Donaldson et al. 2009). Furthermore, Japanese women declaring to like salty foods had a higher BMI compared to those who disliked them (Hashimoto et al. 2008). Also, results from the French web-based observational cohort of the Nutrinet-Santé study showed that overall liking scores for salt and fat were linearly positively related to BMI in 46909 adults and were higher in obese than in normal-weight persons (Deglaire et al. 2015). However, no effect of BMI on salty taste perceptions was shown in other studies (Malcolm et al. 1980; Simchen et al. 2006).

Salt detection threshold after bariatric surgery was only addressed by few studies. In rats, no effect of gastric bypass on salt preference scores was found (Bueter et al. 2011). Similar to our study, Scruggs et al. also found no significant differences in the salt detection threshold between morbid obese patients compared to lean controls (Scruggs et al. 1994). However, in some contrast to our study the salt detection threshold 30, 60 


\section{Manuscript to be reviewed}

or 90 days after bariatric surgery declined non-significantly, indicating a trend for an increased sensitivity. One major reason for this discrepancy may be the very low sample size of 6 individuals in the study of Scruggs et al. (1994). Furthermore, Scruggs et al. used higher salt concentrations and a different method for the tests, all which could have explained the diverging results. In another recent study, Pepino et al. (Pepino et al. 2014) showed no effect of bariatric surgery and weight loss on sodium chloride detection threshold in 27 obese women (Pepino et al. 2014).

We also studied the liking of cream soups differing in their salt concentrations, since taste thresholds may be less representative for daily life. We found no significant differences between the patients and the controls and no effect of bariatric surgery and weight loss on hedonic responses. However, interestingly, considerable sex dependent differences were detected, as the women in our study did not like the cream soups. We also analysed soup liking between controls and patients and before and after surgery in women and men separately, and, similar to the outcome in the whole group, in both cases the results were not significant.

The reasons for the unexpected lower soup liking scores in women compared to men are unclear. Possibly lower intakes of milk and milk products in women may be an explanation. This was for example shown in a large sample by Klesges et al. with nonHispanic white women experiencing more gastric stress after milk consumption than men (Klesges et al. 1999). In addition, gender specific differences in liking of sweet, fatty or salty foods (Deglaire et al. 2015) or taste acuity (Mojet et al. 2003) may also be relevant. However, to the best of our knowledge we found no studies looking at sex differences in the liking of dairy products. Furthermore, it has been suggested that the taste of women may be affected by the various phases of the menstrual cycle (Verma et al. 2005). A further reason for the sex specific differences may be a more frequent dieting behavior in women which may have lead to avoidance or disliking of cream soups by (dieting) women. In conclusion, further studies are needed to confirm these results.

Previous studies suggested an association between BMI and liking for salt (Deglaire et al. 2015; Donaldson et al. 2009) and it has been shown that higher urinary sodium excretions, as an indicator of salt intake, is associated with increased body weight (Huh et al. 2015; Libuda et al. 2012) .Therefore, we also evaluated the salt eating behavior of 
the participants with a short questionnaire and found no differences between obese and lean persons in the preference for use and awareness of salt in food.

One limitation of the study was that the salt intake of the participants was not evaluated. In this regard a recent study found an association between salt intake and salty taste sensibility among hypertensive and normotensive individuals (Piovesana Pde et al. 2013). However, since there were no differences between the usage of salt between patients and controls we believe that there might be no relevant differences in the salt intake between the study groups. Another limitation is the relatively high drop out rate of the patients after bariatric surgery resulting in a lower statistical power in the analysis of the effects of weight loss on the salt detection threshold. Finally, although we additionally studied soup liking, we did not analysed systematically suprathreshold intensity ratings, as an additional way to evaluate hedonic components of higher levels of salt stimuli. This is also a drawback of this study. In general, in a previous study it was suggested that taste function is very complex and difficult to characterize (Webb et al. 2015).

In conclusion, in our study obesity was not associated with an altered salty taste or salting of a taste soup. Bariatric surgery with weight loss may tend to worsen the salt detection threshold of obese patients, although studies with higher sample sizes are necessary. Furthermore, sex should be considered when conducting sensory studies.

\section{Acknowledgement}

The authors like to thank Prof. Regina Sommer and her team from the Water Hygiene Unit, Institute for Hygiene and Applied Immunology, Medical University of Vienna, for technical support. 


\section{References}

American Society for Testing and Materials - ASTM (2011) Standard Practice E67904: Determination of Odour and Taste Threshold by a ForcedChoice Ascending Concentration Series Method of Limits. West Conshohocken, PA

Bartoshuk LM (1978) The psychophysics of taste. Am J Clin Nutr 31 (6):1068-1077

Bray GA, Barry RE, Benfield JR, Castelnuovo-Tedesco P, Rodin J (1976) Intestinal bypass surgery for obesity decreases food intake and taste preferences. Am J Clin Nutr 29 (7):779-783

Bueter M, Miras AD, Chichger H, Fenske W, Ghatei MA, Bloom SR, Unwin RJ, Lutz TA, Spector AC, le Roux CW (2011) Alterations of sucrose preference after Roux-en-Y gastric bypass. Physiol Behav 104 (5):709-721. doi:10.1016/j.physbeh.2011.07.025

Bundesministerium für Verbraucherschutz Ernährung und Landwirtschaft (2008) Fragebogen Nationale Verzehrsstudie II "Was esse ich". Die bundesweite Befragung zur Ernährung von Jugendlichen und Erwachsenen.

Burge JC, Schaumburg JZ, Choban PS, DiSilvestro RA, Flancbaum L (1995) Changes in patients' taste acuity after Roux-en-Y gastric bypass for clinically severe obesity. J Am Diet Assoc 95 (6):666-670. doi:10.1016/S0002-8223(95)00182-4

Deglaire A, Mejean C, Castetbon K, Kesse-Guyot E, Hercberg S, Schlich P (2015) Associations between weight status and liking scores for sweet, salt and fat according to the gender in adults (The Nutrinet-Sante study). Eur J Clin Nutr 69 (1):40-46. doi:10.1038/ejcn.2014.139

Donaldson LF, Bennett L, Baic S, Melichar JK (2009) Taste and weight: is there a link? Am J Clin Nutr 90 (3):800S-803S. doi:10.3945/ajcn.2009.27462Q

Drewnowski A (1997) Taste preferences and food intake. Annu Rev Nutr 17:237-253. doi:10.1146/annurev.nutr.17.1.237

Ekmekcioglu C, Blasche G, Dorner TE (2013) Too much salt and how we can get rid of it. Forsch Komplementmed 20 (6):454-460. doi:10.1159/000357413

Hashimoto T, Yagami F, Owada M, Sugawara T, Kawamura M (2008) Salt preference according to a questionnaire vs. dietary salt intake estimated by a spot urine method in participants at a health check-up center. Intern Med 47 (5):399-403

Huh JH, Lim JS, Lee MY, Chung CH, Shin JY (2015) Gender-specific association between urinary sodium excretion and body composition: Analysis of the 20082010 Korean National Health and Nutrition Examination Surveys. Metabolism 64 (7):837-844. doi:10.1016/j.metabol.2015.03.010

Kim HJ, Paik HY, Lee SY, Shim JE, Kim YS (2007) Salt usage behaviors are related to urinary sodium excretion in normotensive Korean adults. Asia Pac J Clin Nutr $16(1): 122-128$

Klesges RC, Harmon-Clayton K, Ward KD, Kaufman EM, Haddock CK, Talcott GW, Lando HA (1999) Predictors of milk consumption in a population of 17- to 35year-old military personnel. J Am Diet Assoc 99 (7):821-826; quiz 827-828. doi:10.1016/S0002-8223(99)00195-9

Libuda L, Kersting M, Alexy U (2012) Consumption of dietary salt measured by urinary sodium excretion and its association with body weight status in healthy children and adolescents. Public Health Nutr 15 (3):433-441. doi:10.1017/S1368980011002138

Lim SS, Vos T, Flaxman AD, Danaei G, Shibuya K, Adair-Rohani H, Amann M, Anderson HR, Andrews KG, Aryee M, Atkinson C, Bacchus LJ, Bahalim AN, Balakrishnan K, Balmes J, Barker-Collo S, Baxter A, Bell ML, Blore JD, Blyth 
F, Bonner C, Borges G, Bourne R, Boussinesq M, Brauer M, Brooks P, Bruce NG, Brunekreef B, Bryan-Hancock C, Bucello C, Buchbinder R, Bull F, Burnett RT, Byers TE, Calabria B, Carapetis J, Carnahan E, Chafe Z, Charlson F, Chen H, Chen JS, Cheng AT, Child JC, Cohen A, Colson KE, Cowie BC, Darby S, Darling S, Davis A, Degenhardt L, Dentener F, Des Jarlais DC, Devries K, Dherani M, Ding EL, Dorsey ER, Driscoll T, Edmond K, Ali SE, Engell RE, Erwin PJ, Fahimi S, Falder G, Farzadfar F, Ferrari A, Finucane MM, Flaxman S, Fowkes FG, Freedman G, Freeman MK, Gakidou E, Ghosh S, Giovannucci E, Gmel G, Graham K, Grainger R, Grant B, Gunnell D, Gutierrez HR, Hall W, Hoek HW, Hogan A, Hosgood HD, 3rd, Hoy D, Hu H, Hubbell BJ, Hutchings SJ, Ibeanusi SE, Jacklyn GL, Jasrasaria R, Jonas JB, Kan H, Kanis JA, Kassebaum N, Kawakami N, Khang YH, Khatibzadeh S, Khoo JP, Kok C, Laden F, Lalloo R, Lan Q, Lathlean T, Leasher JL, Leigh J, Li Y, Lin JK, Lipshultz SE, London S, Lozano R, Lu Y, Mak J, Malekzadeh R, Mallinger L, Marcenes W, March L, Marks R, Martin R, McGale P, McGrath J, Mehta S, Mensah GA, Merriman TR, Micha R, Michaud C, Mishra V, Mohd Hanafiah K, Mokdad AA, Morawska L, Mozaffarian D, Murphy T, Naghavi M, Neal B, Nelson PK, Nolla JM, Norman R, Olives C, Omer SB, Orchard J, Osborne R, Ostro B, Page A, Pandey KD, Parry CD, Passmore E, Patra J, Pearce N, Pelizzari PM, Petzold M, Phillips MR, Pope D, Pope CA, 3rd, Powles J, Rao M, Razavi H, Rehfuess EA, Rehm JT, Ritz B, Rivara FP, Roberts T, Robinson C, Rodriguez-Portales JA, Romieu I, Room R, Rosenfeld LC, Roy A, Rushton L, Salomon JA, Sampson U, Sanchez-Riera L, Sanman E, Sapkota A, Seedat S, Shi P, Shield K, Shivakoti R, Singh GM, Sleet DA, Smith E, Smith KR, Stapelberg NJ, Steenland K, Stockl H, Stovner LJ, Straif K, Straney L, Thurston GD, Tran JH, Van Dingenen R, van Donkelaar A, Veerman JL, Vijayakumar L, Weintraub $\mathrm{R}$, Weissman MM, White RA, Whiteford H, Wiersma ST, Wilkinson JD, Williams HC, Williams W, Wilson N, Woolf AD, Yip P, Zielinski JM, Lopez AD, Murray CJ, Ezzati M, AlMazroa MA, Memish ZA (2012) A comparative risk assessment of burden of disease and injury attributable to 67 risk factors and risk factor clusters in 21 regions, 1990-2010: a systematic analysis for the Global Burden of Disease Study 2010. Lancet 380 (9859):2224-2260. doi:10.1016/S0140-6736(12)61766-8

Ma Y, He FJ, MacGregor GA (2015) High salt intake: independent risk factor for $\begin{array}{llll}\text { obesity? } & \text { Hypertension } & 66 & \text { (4):843-849. }\end{array}$ doi:10.1161/HYPERTENSIONAHA.115.05948

Malcolm R, O'Neil PM, Hirsch AA, Currey HS, Moskowitz G (1980) Taste hedonics and thresholds in obesity. Int J Obes 4 (3):203-212

Maliphol AB, Garth DJ, Medler KF (2013) Diet-induced obesity reduces the responsiveness of the peripheral taste receptor cells. PLoS One 8 (11):e79403. doi:10.1371/journal.pone.0079403

Mojet J, Heidema J, Christ-Hazelhof E (2003) Taste perception with age: generic or specific losses in supra-threshold intensities of five taste qualities? Chem Senses 28 (5):397-413

Overberg J, Hummel T, Krude H, Wiegand S (2012) Differences in taste sensitivity between obese and non-obese children and adolescents. Arch Dis Child 97 (12):1048-1052. doi:10.1136/archdischild-2011-301189

Parmenter K, Wardle J (1999) Development of a general nutrition knowledge questionnaire for adults. Eur J Clin Nutr 53 (4):298-308 
Pasquet P, Frelut ML, Simmen B, Hladik CM, Monneuse MO (2007) Taste perception in massively obese and in non-obese adolescents. Int J Pediatr Obes 2 (4):242248. doi:10.1080/17477160701440521

Peng M, Jaeger SR, Hautus MJ (2012) Determining odour detection thresholds: Incorporating a method-independent definition into the implementation of ASTM E679. Food Quality and Preference 25 (2):95-104. doi:http://dx.doi.org/10.1016/j.foodqual.2012.02.006

Pepino MY, Bradley D, Eagon JC, Sullivan S, Abumrad NA, Klein S (2014) Changes in taste perception and eating behavior after bariatric surgery-induced weight loss in women. Obesity (Silver Spring) 22 (5):E13-20. doi:10.1002/oby.20649

Piovesana Pde M, Sampaio Kde L, Gallani MC (2013) Association between Taste Sensitivity and Self-Reported and Objective Measures of Salt Intake among Hypertensive and Normotensive Individuals. ISRN Nutr 2013:301213. doi:10.5402/2013/301213

Sartor F, Donaldson LF, Markland DA, Loveday H, Jackson MJ, Kubis HP (2011) Taste perception and implicit attitude toward sweet related to body mass index and soft drink supplementation. Appetite 57 (1):237-246. doi:10.1016/j.appet.2011.05.107

Scruggs DM, Buffington C, Cowan GS, Jr. (1994) Taste Acuity of the Morbidly Obese before and after Gastric Bypass Surgery. Obes Surg 4 (1):24-28. doi:10.1381/096089294765558854

Simchen U, Koebnick C, Hoyer S, Issanchou S, Zunft HJ (2006) Odour and taste sensitivity is associated with body weight and extent of misreporting of body weight. Eur J Clin Nutr 60 (6):698-705. doi:10.1038/sj.ejcn.1602371

Spector AC (2000) Linking gustatory neurobiology to behavior in vertebrates. Neurosci Biobehav Rev 24 (4):391-416

Tichansky DS, Boughter JD, Jr., Madan AK (2006) Taste change after laparoscopic Roux-en-Y gastric bypass and laparoscopic adjustable gastric banding. Surg Obes Relat Dis 2 (4):440-444. doi:10.1016/j.soard.2006.02.014

Verma P, Mahajan KK, Mittal S, Ghildiyal A (2005) Salt preference across different phases of menstrual cycle. Indian J Physiol Pharmacol 49 (1):99-102

Webb J, Bolhuis DP, Cicerale S, Hayes JE, Keast R (2015) The Relationships Between Common Measurements of Taste Function. Chemosens Percept 8 (1):11-18. doi:10.1007/s12078-015-9183-x

Webster JL, Li N, Dunford EK, Nowson CA, Neal BC (2010) Consumer awareness and self-reported behaviours related to salt consumption in Australia. Asia Pac J Clin Nutr 19 (4):550-554 


\section{1}

Estimated salt detection threshold between patients before and after bariatric surgery and controls

Fig 1. A: Estimated salt detection threshold (in $\mathrm{g} \mathrm{NaCl} / \mathrm{L}$ ) between patients before bariatric surgery $(n=33)$ and controls $(n=29)$. Mean values were not significantly different. B: Estimated salt detection threshold (in $\mathrm{g} \mathrm{NaCl/L)}$ ) between patients before vs. after bariatric surgery (both $n=19$ ). Mean values were not significantly different. 
A

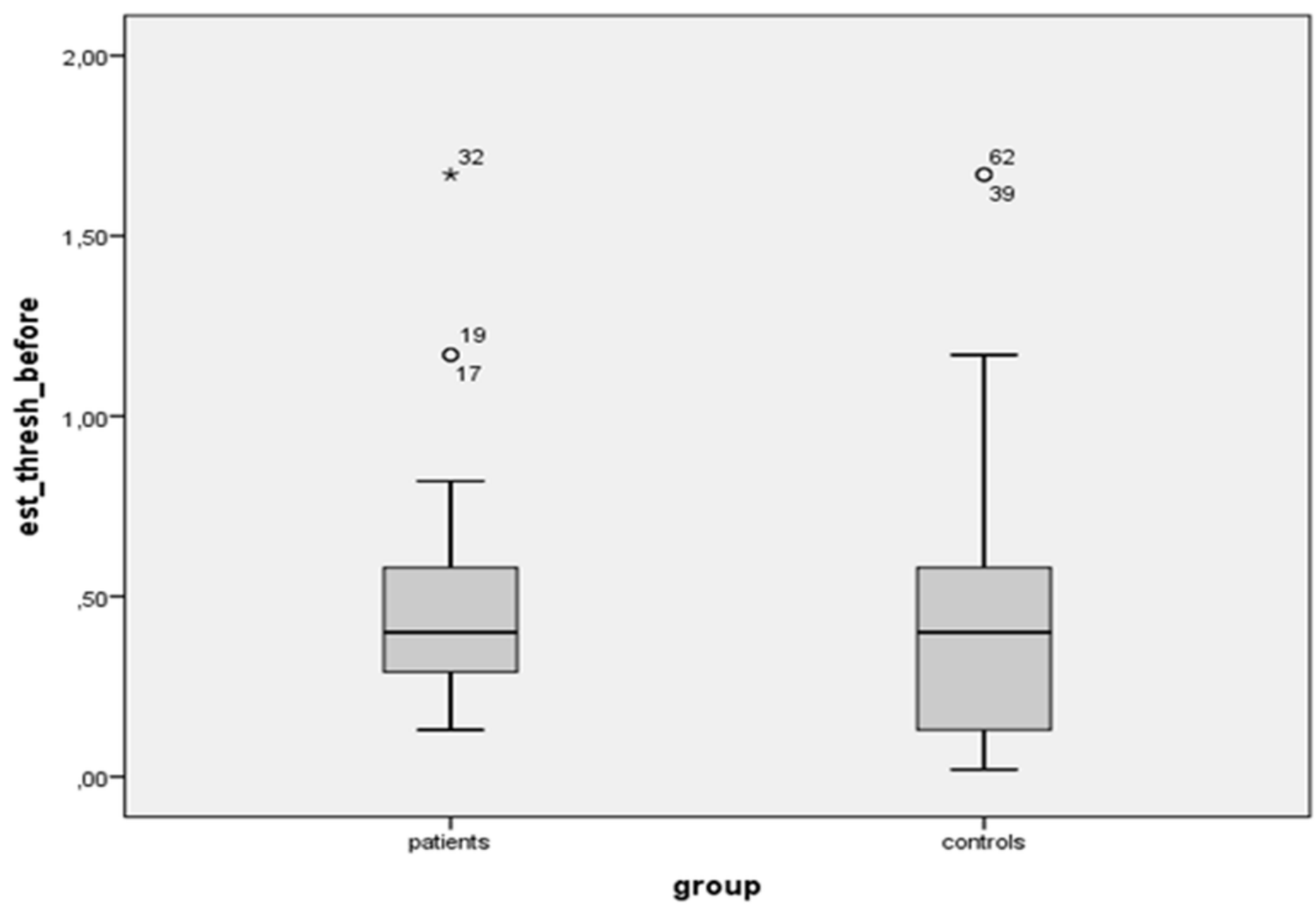

B

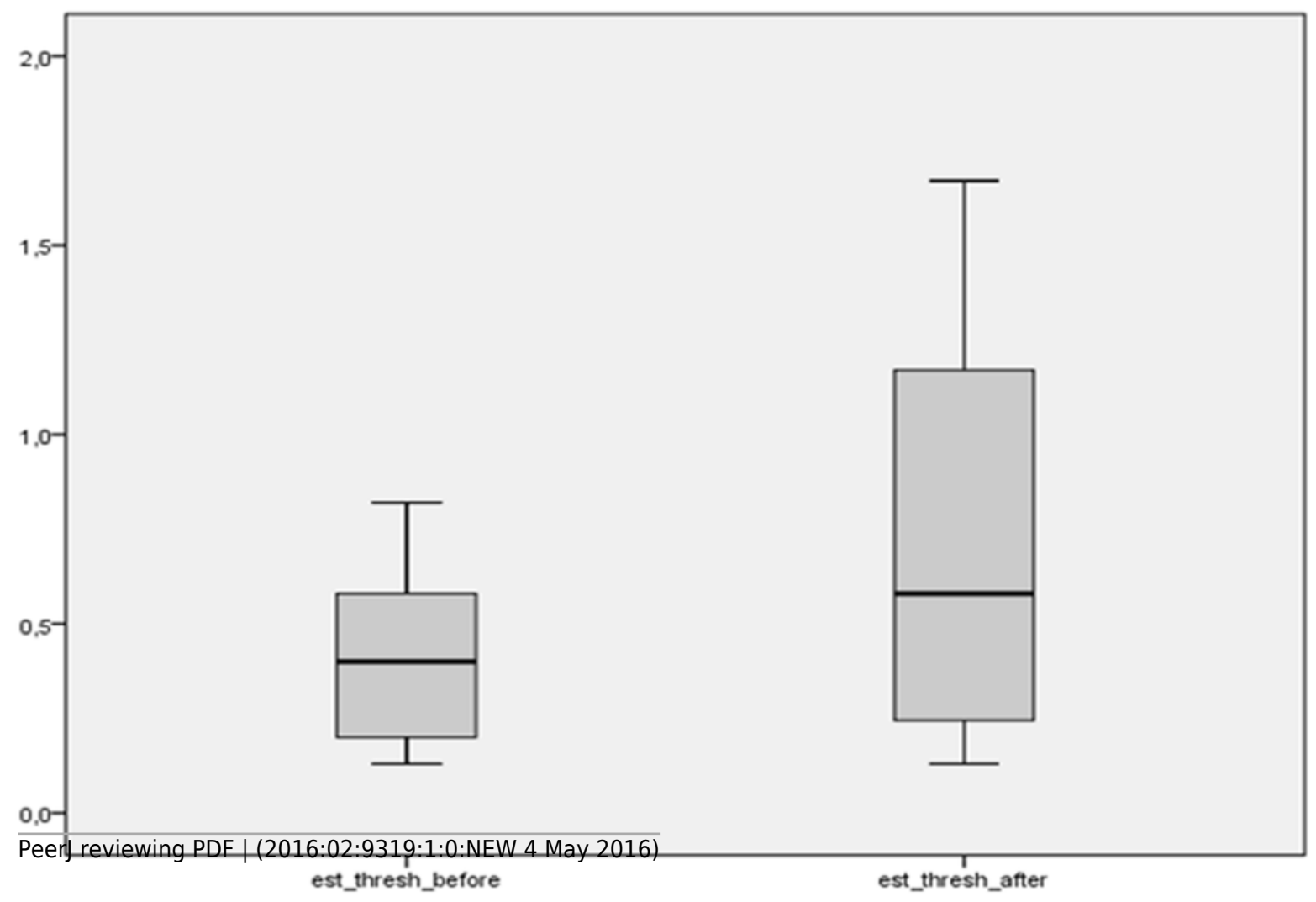


2

Soup liking between patients vs. controls (A) and also sex specific effects (B)

Soup liking between patients (as the weighted mean, WM) vs. controls (A) and also sex specific effects (B) were analysed with a univariate analysis of variance with the weighted mean of the soup liking (soup 1 was weighted with 1 and soup 5 with 5) as the dependent variable, group and sex as factors and age and BMI before surgery as covariates. $A=$ no statistical difference between patients vs. controls. $B={ }^{*}$ significantly lower than males $(p<$ $0.001)$ 


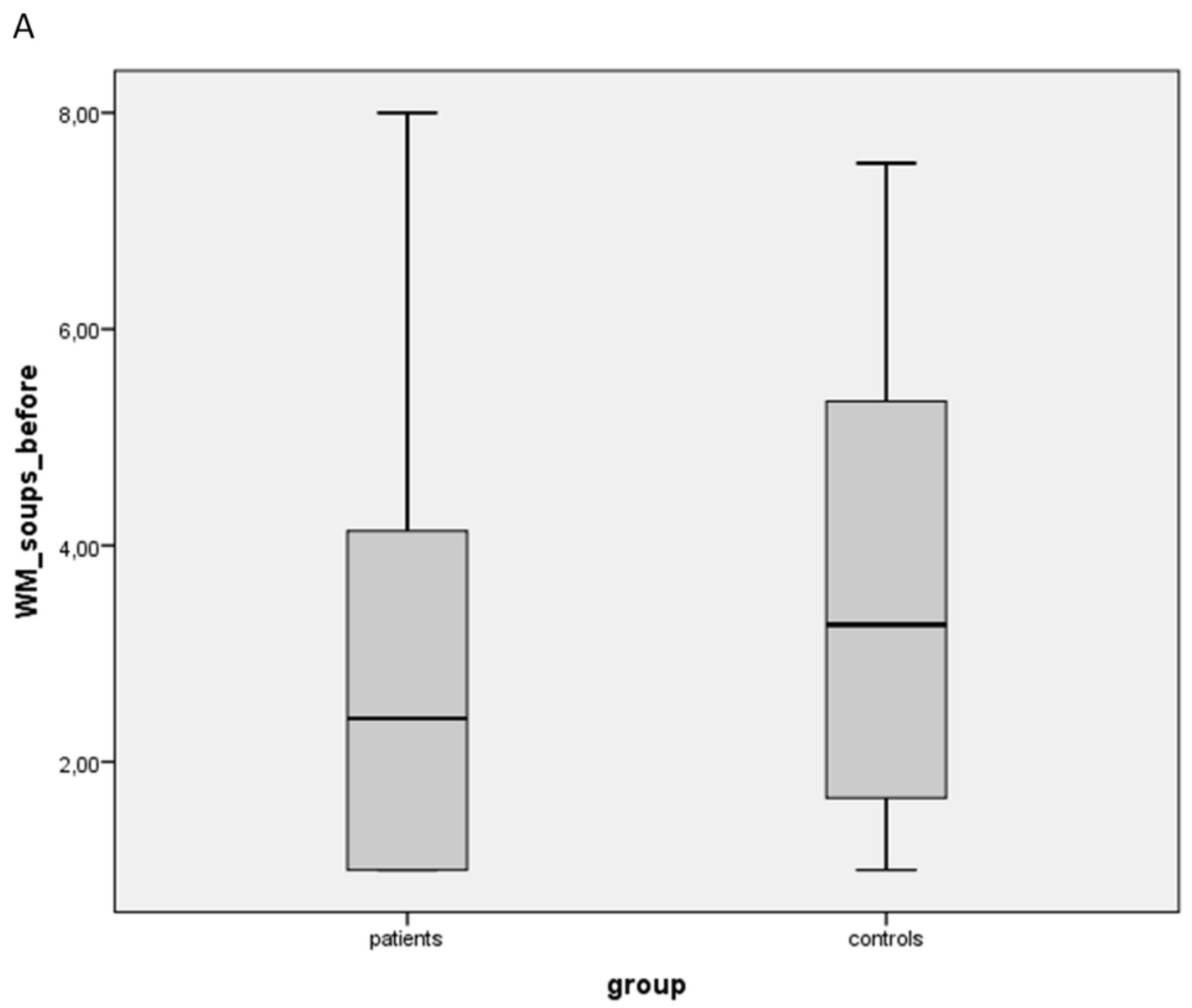

B

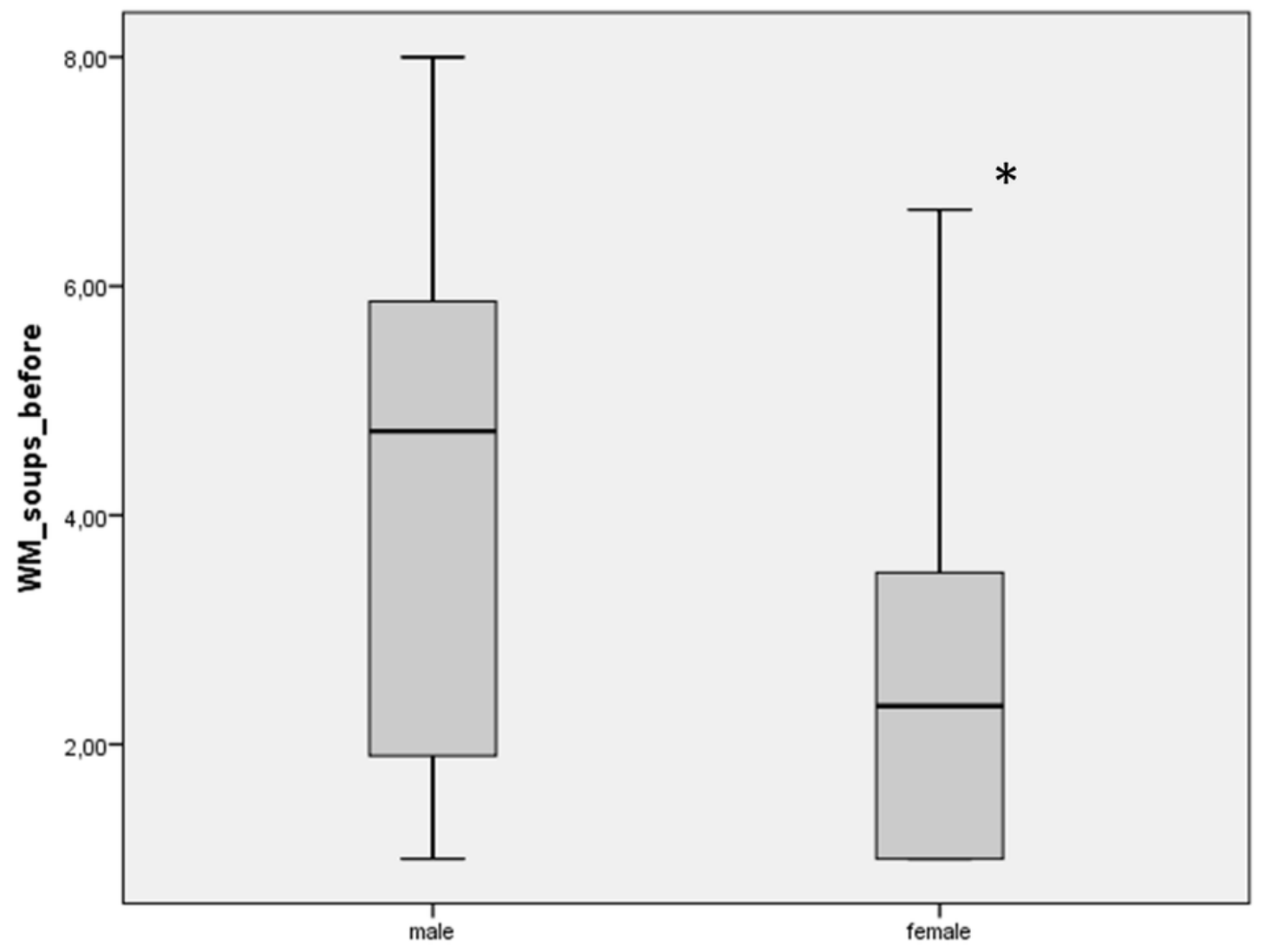

PeerJ reviewing PDF | (2016:02:9319:1:0:NEW 4 Mał 2016$)$ 
Table $\mathbf{1}$ (on next page)

Characterization of the study groups 
1 Table 1. Characterization of the study groups

\begin{tabular}{|c|c|c|c|c|c|}
\hline Group & Gender & $\begin{array}{c}\text { Age } \\
\text { (years, mean } \pm \text { SD) }\end{array}$ & $\begin{array}{c}\text { BMI }\left[\mathrm{kg} / \mathrm{m}^{2},\right. \\
\operatorname{mean} \pm \mathrm{SD}]\end{array}$ & $\begin{array}{c}\text { BMI, } 3 \text { months post } \\
\text { OP }[\text { mean } \pm \text { SD, } \\
\text { kg/m²] }\end{array}$ & Major comorbidities \\
\hline $\begin{array}{l}\text { Controls } \\
(n=29)\end{array}$ & Female: 14 & $\begin{array}{c}41.0 \pm 12.8 \\
\text { (range: } 22-62 \text { ) }\end{array}$ & $\begin{array}{c}23.6 \pm 3.0 \\
\text { (range:16-28) }\end{array}$ & n.a. & No indicated \\
\hline $\begin{array}{c}\text { Patients } \\
\text { (n = 33; } \\
\text { post OP: n } \\
\quad=19)\end{array}$ & Female:21 & $\begin{array}{c}46.3 \pm 10.0 \\
\text { (range: } 23-65 \text { ) }\end{array}$ & $\begin{array}{c}43.2 \pm 5.7 \\
\text { (range: } 30-51 \text { ) }\end{array}$ & $\begin{array}{c}33.8 \pm 5.0 \\
\text { (range:22-42) }\end{array}$ & $\begin{array}{c}\text { Hypertension: } 17 \\
\text { Diabetes:10 }\end{array}$ \\
\hline
\end{tabular}

2 n.a.: not applicable

3 
Table 2 (on next page)

Examples of the salt threshold measurement 
1 Table 2. Examples of the salt threshold measurement.

\begin{tabular}{|c|c|c|c|c|c|c|c|c|c|}
\hline \multirow[t]{3}{*}{ Participants } & \multicolumn{9}{|c|}{ Judgments } \\
\hline & \multicolumn{8}{|c|}{$\mathrm{NaCl}$ Concentrations increase $\rightarrow[\mathrm{g} \mathrm{NaCl} / \mathrm{L})]$} & $\begin{array}{l}\text { Best estimate } \\
\text { threshold (BET) } \\
{[\mathrm{g} \mathrm{NaCl/L)]}}\end{array}$ \\
\hline & 0.16 & 0.24 & 0.34 & 0.48 & 0.69 & 0.98 & 1.4 & 2 & \\
\hline 1 & 0 & 0 & 0 & 0 & 1 & 1 & 1 & 1 & 0.58 \\
\hline 2 & 1 & 0 & 1 & 0 & 0 & 1 & 1 & 1 & 0.82 \\
\hline
\end{tabular}

2 
Table 3 (on next page)

Liking scores for cream soups 


\section{Table 3: Liking scores for cream soups}

\begin{tabular}{|l|l|l|}
\hline \multicolumn{2}{|c|}{ 9-Point Hedonic Scale } & \multirow{2}{*}{ Liking area } \\
\hline 9 & Like Extremely & \\
\hline 8 & Like Very Much & \\
\hline 7 & Like Moderately & \multirow{2}{*}{ Neutral } \\
\hline 6 & Like Slightly & \multirow{2}{*}{ Dislike area } \\
\hline 5 & Neither Like nor Dislike & \\
\hline 4 & Dislike Slightly & \\
\hline 3 & Dislike Moderately & \\
\hline 2 & Dislike Very Much & \\
\hline 1 & Dislike Extremely & \\
\hline
\end{tabular}

2 


\section{Table 4(on next page)}

Liking scores of soups 1-5 in controls and patients before and after OP 
1 Table 4: Liking scores of soups 1-5 in controls and patients before and after OP

\begin{tabular}{|c|c|c|c|c|c|}
\hline Group & Soup 1 & Soup 2 & Soup 3 & Soup 4 & Soup 5 \\
\hline Control (n=29) & $3.59 \pm 2.31$ & $4.24 \pm 2.33$ & $4.14 \pm 2.55$ & $3.45 \pm 2.41$ & $2.93 \pm 2.20$ \\
\hline $\begin{array}{c}\text { Patients before } \\
\text { surgery (n=33) }\end{array}$ & $2.79 \pm 2.04$ & $2.79 \pm 2.38$ & $2.88 \pm 2.36$ & $3.42 \pm 2.66$ & $2.88 \pm 2.66$ \\
\hline $\begin{array}{c}\text { Patients after } \\
\text { surgery (n=19) }\end{array}$ & $2.89 \pm 1.82$ & $2.58 \pm 1.90$ & $2.05 \pm 1.68$ & $2.21 \pm 1.96$ & $1.74 \pm 1.41$ \\
\hline
\end{tabular}

2 Values are shown as mean $\pm \mathrm{SD}$ 